\title{
Gender Equality and Taxation - International Perspectives
}

\author{
Åsa Gunnarsson ${ }^{1}$ \\ Umeå University, Sweden
}

\begin{abstract}
The National tax laws and international tax policies have, despite impressive growth performances in many economies, worked against economic gender equality. The broad concept of tax fairness has become equivalent to what is good for economic growth and detached from social justice, leading to increasing income gaps and poverty. As a result, many aspects of taxation have indirectly had a substantial effect on gender-related socio-economic inequalities even though most domestic tax laws being gender neutral. The ignorance to consider gender inequalities, when designing tax laws, is obviously in conflict with several legal obligations and policies, on national, regional and international levels.

In this paper, novel insights concerning the relationship between gender equality and taxation are presented. These insights have been pushed forward by both the societal challenges of financial crisis and now the pandemic crisis. Based on legal and economic perspectives, the anlysis in the text provides an overview of gender aspects within taxation when related to current tax policy trends.
\end{abstract}

Keywords: Tax policy, gender equality, tax principles, tax reform.

\section{Introduction}

The outbreak of Covid-19 coincides with the twenty-fifth anniversary of the Beijing Platform for Action. For the UN, 2020 was intended to be groundbreaking for gender equality initiatives. Instead, UN claim that the ongoing spread of the pandemic is risking the limited gains regarding gender equality made in the past. At the same time as the pandemic is deepening pre-existing inequalities, exposing vulnerabilities in social, political and

\footnotetext{
${ }^{1}$ Email: asa.gunnarsson@umu.se.
} 
economic systems, across every sphere, from health to the economy, security to social protection, the impacts of COVID-19 are exacerbated for women and girls simply by virtue of their sex. Compounded socio-economic impacts are felt especially by women of all ages who are generally earning less, saving less, carrying a heavier burden of unpaid work, holding insecure jobs or living close to poverty. This is why Secretary-General did call to action on the basis on human rights, pointing out three cross-cutting priorities; ensure women's equal representation in all covid-19 response planning and decision-making, drive transformative change for equality by addressing the paid and unpaid care economy, and thirdly, target women and girls in all effort to address the socio-economic impact of Covid-19 (UN 2020).

In contrast to these UN ambitions, tax reforms during the last decades have shaped tax systems that are contradictory to the resource mobilization and redistribution that are necessary for the realization of human rights. It is obvious that Agenda 2030 demands a reset of this development and the reformation of fiscal systems with the ambition to combat poverty, which is a relevant issue for women with low incomes and limited resources in every country of the world.

Although most domestic tax laws apply equally to men and women, tax systems and fiscal policy decisions affect men and women differently. Many aspects of taxation have indirectly a substantial effect on gender-related socioeconomic inequalities. The persisting gender differences in employment rates and patterns and gender gaps in unpaid care work, employment rates, income, old age security, poverty and wealth are all closely linked to the allocative and distributional outcome of tax regulations (Gunnarsson, Schrazenstaller, and Spangenberg 2017).

Historically, tax laws are one of most important instruments for governments with redistributive ambitions. In welfare economies, taxes have been used to reduce economic inequalities for the well-being of citizens. A large part of these redistributive tax measures has, based on various objectives, been directed to families. Household-based tax schemes in the form of tax credits or basic deductions with the aim to support lowincome families is one example. Another is joint tax measures for spouses to support a particular family-model such as the bread-winner family. All 
these redistributive family/household-oriented tax policies and regulations, are connected to obvious gender equality implications, which very seldom have been recognized (Gunnarsson 2013).

In developing countries, gender equality tax issues are not located to direct income taxes, but indirect taxes. VAT and other goods and services taxes have been of central importance for resource mobilization in the majority of low- and medium-income countries (Cottarelli 2011). As an effect, the overall tax systems in these countries have been more regressive than progressive. As women are over-represented among the poorest, the regressive profile is not only a low-income issue, but also a gender issue. Kathleen Lahey has connected this tax related gender equality issue to the fundamental tax equity principle of ability-to pay. She claims that the principle should be regarded as fundamental to tax policy and human rights. To tax those on the margins of survival, that have no ability to pay taxes, "...violates constitutional and human rights to life and equality" (Lahey 2018).

The basic problem is, that even though numerous states and global entities guarantee political and economic gender equality, tax policies and tax laws, generally are not based on considerations related to these goals. In our study of gender equality and taxation in the European Union, requested by the European Parliament's Committee on Women's Right and Gender Equality, we could confirm that the European Institutions nor the Member States complied with the legal obligations and political commitments regarding gender equality in the field of taxation. Compliance with these obligations needs at the least, regular impact assessments of all fiscal policies from a gender equality perspective, including proposals for tax legislation and soft law procedures (Gunnarsson, Schrazenstaller, and Spangenberg 2017).

Regarding perspective and structure, this article builds on the overview of the state-of-the-art research regarding in the EU-study, adding new insights from gender research on taxation. The article also builds on the critical epistemology developed by gender studies that have challenged the basic ontological categories, concepts and presumptions upon which tax laws and public budgets are built (Brooks et al. 2011; Gunnarsson 2013). The traditional view on tax fairness and tax efficiency principles will be 
particularly challenged on the basis of a critical tax policy framework that also include social justice and human rights as a part the tax policy discourse (Gunnarsson 2018; Gunnarsson 2020).

The text starts with a discussion on the need to change the long-term tax policy agenda to a concept based on the empowering of women in line with both Agenda 2030 and gender equality obligations regarding taxation. After the meta-level discussion on policies and obligations follows a critical review from the perspective of socio-economic gender inequalities regarding both issues on the distributive profile on the general tax mix and the different categories of tax bases. The case study on the EU will be complemented with other regional, national and international findings on structural, indirect discriminatory practices as an outcome of tax policies and provisions. Finally, an effort is made to frame the gender equality dimension of the destructive loss of tax revenue through the use of secrecy jurisdictions.

\section{Neoliberal tax policy - Growth promotion as the one-way-message}

Fiscal taxation for economic growth, implemented with tax neutrality as a guiding principle, has since the beginning of the 1980s, become a dominant view on tax sustainability. Tax neutrality bench-marks taxes that distort the economic efficiency of market processes as little as possible, implying a trade-off between efficiency and equity. Redistributive taxes and transfers are regarded to negatively affect incentives to work, save, and earn income. The idea of a trade-off between equity and efficiency, is at the core of the optimal income tax problem.

This has been described as an ideological hegemony, that on a global scale has institutionalized a one-path model for taxing for economic growth in tax law design. The main features of these tax reforms can briefly be summarized as follows: broader labor incomes tax bases but low progressivity; a moderate taxation of capital and corporations; uniform tax rates are applied on the consumption of goods and services; introduction of in-work tax subsidies; a shift from direct taxes to indirect taxes (Sandford 1993; Messere 1998; Sørensen 2010; Gunnarsson, Schrazenstaller, and Spangenberg 2017). 


\section{Emerging trend on inclusive growth strategies and taxation}

Based on lessons learnt from past financial crises, economic recessions and increasing levels of income inequalities over the last decades in advanced economies, both scholarly and political reconsiderations of the taxing for growth paradigm have evolved. A new wave of research with a stronger focus on the relations between inequalities, taxation and economic growth has emerged among economists after Thomas Piketty's book Capital in the Twenty-First Century (2014). Concerns about the harmfulness of increasing income and wealth inequalities have been raised, which has framed a point of departure for critical analysis. One outcome is the literature on income inequality, which has revealed the rise of top incomes over time and explored options on how top earners can pay more taxes (Förster, LlenaNozal and Nafilyan 2015.

An awareness of combining growth promoting tax reforms with analyses and policies on economic inequalities has also grown in institutions that earlier only promoted the one-way message, such as the European Commission (EC), the OECD and the International Monetary Fund (IMF). The changing view is related to the statement in Agenda 2030 about creating conditions for inclusive and sustained economic growth (United Nations General Assembly 2015, para 3).

The change is also related to research and policy reports in these organizations that have combined growth- and equality-enhancing perspectives, resulting in conclusions that inequality in the end will have negative effects on growth promotion (Ostry, Berg and Tsangarides 2014). Empowering women in the economy and closing gender gaps in the world of work are by the UN regarded as a key to achieving the 2030 Agenda for Sustainable Development. The message is that when more women work, economies grow (UN 2016). UN refers to figures and policies produced by the IMF, on how women's economic empowerment boosts productivity, increases economic diversification and income equality in addition to other positive development outcomes (IMF 2018). For example, the PwC Women in Work Index 2020 shows that if increasing the female employment rates in OECD countries to match that of Sweden, could boost GDP by over USD 
6 trillion. Interesting is also to note the existence of estimations that gender gaps could cost the economy some 15 percent of GDP (Cuberes and Teigner 2016; Ferrante and Kolev 2016).

The OECD new policy turn was documented in the initiative called New Approach to Economic Challenges, which recommends the adoption of longer-term perspectives in the institutional setting on how economies are shaped by history, social norms and political choices. The new policy is defined as 'tax design for inclusive growth' and launches four basic tax principles to support the policyBroadening tax bases: Strengthening the overall progressivity of the fiscal system; Affecting pre-tax behaviors and opportunities; Enhancing tax policy and administration (OECD 2015).

The OECD researcher also makes a long list of additional work to develop the concept of inclusive growth. Those most relevant from a human right perspective are on the relation between taxation and gender and on taxes that can strengthen equality of opportunity (Brys et al. 2016). IMF has come to a similar conclusion, when arguing for a policy direction on tax measures to fulfill the 2030 Agenda (Gaspar et al. 2019).

\section{Gender equality and inclusive growth}

Diane Elson and Marzia Fontana (2019) have come to the conclusion that gender-equitable inclusive growth must result in no irreparable harm to the well-being of women and men. Hereby, the inclusiveness concept is in line with the basic principle for sustainability, given already in 1987, that serves well as a human rights perspective. In a report from the World Commission on the Environment and Development (1987), the principle was formulated as stating that future development of the planet would be considered sustainable if the present generation were able to satisfy its own needs, without compromising the ability of future generations to do so as well. To make taxation a part in the progress in ensuring a sustainable future for its citizens, five dimensions of tax policies for sustainable tax systems ought to be considered. These are the perspectives of social, economic, environmental, institutional/cultural, and equality (Mumford and Gunnarsson 2019).

Well-being seems to be a central concept for bridging inclusive growth to gender equality. In redressing gender gaps in well-being two aspects of tax 
policy are regarded as relevant- the distributional impact and the overall level of tax revenues, including both direct and indirect taxation (Seguino 2019). The European Parliament (2018/2019 (INI), No. 34) has been very straight forward on the issue and stated that gender equality is not only a fundamental human right in itself, but would contribute to more inclusive and sustainable growth.

\section{Critique of inclusiveness}

However, inclusiveness does not give any direction for how low-income developing countries will be able to raise revenue to cover the additional spending that is necessary to fulfill the SDGs. An estimate from IMF is that these countries in average need to raise an increase of revenue that represents 15\% of their GDP (Gaspar 2019).

Based on distributional equity objectives, the inclusive growth paradigm has been criticized for focusing entirely on market-led growth. A central concern is the alienation from the socio-economic realities of middleincome, poor and transition countries. One line of criticism is that inclusiveness has become a recognition of equality of opportunity, a formal access to possibilities, not part of a substantial, system-oriented view on distributional rights (Saad-Filho 2010).

\section{Legal obligations, political commitments and activism regarding gender equality and taxation}

Policymakers usually do not consider gender inequalities when designing tax laws, even though many aspects of taxation have a substantial effect on gender-related socioeconomic inequalities. Assessments of gender equality in taxation often distinguish between explicit and implicit gender bias (Stotsky 1996; Barnett and Grown 2004; Grown and Valodia 2010; Bettio, and Verashchagina; Joshi 2016). Explicit forms refer to tax provisions that explicitly treat men and women differently. Implicit forms of gender bias describe tax regulations that are written in gender-neutral terms, but affect men and women differently, due to socioeconomic inequalities (Stotsky 1996). 
The ambition of this section is to clarify how normative principles regarding fiscal sustainability and tax fairness have been applied in the drafting of tax law, as an introduction to the empirical account of the historical development of the tax system. In the definition of normative principles we have excluded the constitutional principles of legality and transparency, which are central for all types of regulations.

The distinction between explicit and implicit bias corresponds basically to the legal concept of direct and indirect discrimination, enshrined in domestic and international law. In the following discuss the concepts of direct and indirect discrimination on the basis of both legal obligations and political agreements relevant for formal and substantial equality in regard to taxation.

\section{Direct and indirect discrimination}

Direct (sex) discrimination is generally defined as less favourable treatment with an explicit distinction between different sexes. Indirect discrimination refers to apparently neutral provisions, criteria or practices which (might) result in a particular disadvantage for a person of one sex compared to a person of the other sex, due to existing socioeconomic differences.

However, non-discrimination alone is not sufficient to ensure substantive gender equality aiming for equality in socioeconomic realities. The concept of indirect discrimination expresses more than just a demand on formal equality and gender neutrality in law and legal practises. Indirect discrimination is also a concept that targets gender-differentiated effects of apparently neutral regulations, caused by different socioeconomic realities. Consequently, it is possible to use indirect discrimination as a transformative instrument, but the transformative impact is limited as indirect discrimination can only be applied to selected policy fields and the definition of comparable situations. Furthermore, disadvantages are acceptable if the regulation is justified by a legitimate aim, and if the means of achieving that aim are appropriate and necessary.

Since governments have wide legislative discretion in terms of policy objectives and appropriate means, gender gaps often persist. The positive obligation to ensure gender equality accentuates the necessary change in 
socioeconomic realities. This requires identifying persisting gender gaps and implementing appropriate measures to overcome them. Achieving equality in outcomes might require positive measures, such as specific advantages for women (Gunnarsson, et al, 2017, 16; Grown and Valodia. 2010).

The prohibition of discrimination on grounds of sex and the promotion of gender equality is regulated in the constitution of many national states. Irrespective of constitutional support for anti-discrimination regarding gender, most states in the world are bound by gender equality obligations in human treaties. The Convention on the Elimination of All Forms of Discrimination against Women (CEDAW) is of particular relevance to women's rights. Although the Convention does not explicitly mention taxation, the obligation to prohibit discrimination against women and to ensure substantive equalities applies to all government policies, has been interpreted to also include taxation. Diane Elson was one of the first to apply the CEDAW principles to evaluate direct and indirect taxation in the light of explicit and implicit biases in tax rules, the burden and incidence of taxes, behavioural incentives or responses and the distributional impact of tax on income inequalities (Elson 2006).

There are several provisions relevant to tax policies. For instance, CEDAW assigns rights to women as individuals. Neither marriage nor family relations allow for any kind of discrimination. States are therefore required to analyse the impact of taxation on individuals and not only at household level. Moreover, women's rights to employment and economic independence demands that tax-related disincentives to women's access to employment should be eliminated. Practices based on hierarchies or stereotyped roles for men and women have to be abolished. The design of tax policies should therefore promote the equal sharing of paid and unpaid work between men and women and not violate the prohibition of discrimination in the field of employment and other areas of economic and social life (Elson 2006, 75-75).

The Beijing Platform for Action, which substantiates objectives and measures necessary to achieve substantive gender equality, can also be interpreted to include the need to analyse tax policies from a gender perspective. The CEDAW Committee has, in the monitoring of the Beijing 
Platform, come to emphasize the necessity of that governments in the national reports can show progress in the promotion of substantial gender equality (Fredman2013). As the combat against poverty and inequality is of central concern in the Platform taxes have to be considered. Taxes needs to adjusted in a way that promotes a more equitable distribution of productive assets, wealth, opportunities, income and services (Strategic objective A. 1., No. 58b.). Furthermore, the relevance of gender analyses is highlighted with regard to domestic income tax, inheritance tax and social security systems, as well as with regard to the development of economic and social policies (Strategic objective F. 1. No. $165 \mathrm{f}$ and p.).

UN Women (2015) has also contributed to a strong definition of substantive equality. They claim that the concept should be overarching, calling for women's full factual equality of opportunities and outcomes in all situations. Progress towards substantive equality for women requires public action on three interrelated fronts: redressing socio-economic disadvantage; addressing stereotyping, stigma and violence; and strengthening agency, voice and participation. Transformation in women's lives happens when actions along these three dimensions reinforce each other.

The international human rights system in general, and the CEDAW in particular, recognizes the limitations of formal equality in delivering equality in practice. Within the human rights system and its associated treaties, there is strong support for going beyond formal equality and the provision of 'same treatment'. The concept of substantive equality has been advanced in key human rights treaties to capture this broader understanding: that inequality can be structural and discrimination indirect; that equality has to be understood in relation to outcomes as well as opportunities; and that 'different treatment' might be required to achieve equality in practice.

\section{Political agreements}

In addition, there are political agreements that add another layer to the gender equality framework of taxation. The Sustainable Development Goals adopted by the UN at the end of 2015, apply to all policy fields and define specific outcomes which are also relevant for taxation (UN 2015). The goal 
for gender equality is comprised of nine specific targets. For instance, ending all forms of (direct and indirect) discrimination against women, recognising and valuing unpaid care and domestic work, and ensuring women's full and effective participation at all levels of decision-making. Gender is also mainstreamed into other goals, such as ending poverty, promoting sustained, inclusive and sustainable economic growth, promoting full and productive employment and decent work for all, and reducing inequalities within and between countries. The Addis Ababa Action Agenda underlines the relevance of domestic public resources, including the tax system, as means to achieve the SDGs ( UN Resolution adopted 27 July 2015).

\section{Activism}

The exclusion of women's socio-economic, everyday life living conditions is a global democratic problem, demanding both political recognition and development of a comprehensive knowledge base. During 2017 (Bogotadeclaration), a first global convening with the goal to start a global women's movement campaign on tax justice for women's rights, was held in Bogota, Colombia. A group of activists, researchers and representatives for international organizations drafted a declaration based on the human rights instruments such as the 2030 Agenda for Sustainable Development Goals (SDGs), the UN CSW61 Agreed Conclusions, the Addis Ababa Agenda for Action (Financing for Development 69/313), and the Article 2.1 of the International Covenant on Economic, Social, and Cultural Rights from 1976. The view expressed in the declaration is based on a critique on how tax systems, globally, support and create increasing impoverishment and marginalization of women in the economy. The basic message is that the countries of the world need to create gender responsive fiscal systems to deliver on human rights obligations to their female citizens. In sum the demands are: Stop all forms of tax evasion; Erase all form of unfairness in the tax burden for women; Abolish gender discrimination in tax policies; Resource mobilization through tax revenue to increase government investments in programs that improves gender equality such as public education, health, care services, transportation, food security, and housing. These public investments reduce women's unequal shares of unpaid work 
and increase women's shares of market incomes; Introduce individual tax systems, as well as social benefits systems.

\section{Women's socio-economic realities relevant for allocative and distributional outcomes of tax laws}

Economic inequalities between men and women bring a gendered dimension to policy issues concerning tax equity and social justice. Generalizations about the socio-economic conditions of women are, of course, difficult to make. However, despite the intersections of sex with other demographic factors such as age, race, region and class, inevitable common traits exist in statistical differences between men and women regarding economic status. In general, it is possible to state that men earn more and are wealthier than women. Another notable difference is that women tend to be clustered in lower income groups and have higher poverty rates than men. In the case of EU, the risk is particularly high for elderly, single women to fall under the poverty line (Gunnarsson, Schrazenstaller, and Spangenberg 2017).

One variable of significance for differences in accumulating wealth is that women are less likely to have capital gains income and a financial cushion (Kornhauser 2011). Information from the Global Financial Inclusion database point out that women are less likely than men to have basic economic tools such as access to financial institutions or a bank account (Demirguc-Kunt et al. 2015). The gender gaps in the business sector are large and complex, with huge conditional differences from an international perspective. Women are less likely to be entrepreneurs and face more disadvantages starting businesses, constrained from attracting investment capital. Women are also highly underrepresented from achieving high corporate management positions such as CEOs (UN Women 2018). Nordic studies confirm these observations. Large gaps between female and male entrepreneurship exists regarding structures of corporate forms, ownership and investment capital. The type of business women manage differs from men. Normally, women's companies are livelihood businesses, which produce services and do not attract risk capital. The description 'livelihood companies' refers to enterprises that are established with the 
objective of making a living rather than building a business empire. These types of companies produce a modest profit and have low expectations of wealth accumulation and innovations. Women entrepreneurs are less willing to take financial risks and are less involved in advanced tax planning, tax fraud and evasion (Vada, 2007, 49-59; Andersson-Skog. 2007; Alsos et al. 2016.)

Given these variables regarding differences between men and women one can see that the socio-economic realities of women's lives must be a part of policy making concerning the manner in which work, entrepreneurship and investments are taxed. But analysis cannot be limited to the income side of the public budget if the full context of women's economic subordination is to be grasped. The structures of revenue and social transfers are intertwined in welfare state policies (Young 2000; Stewart 2017). A further important gender aspect is that tax and social security regulations also mirror what the state regards as the preferred way of organizing families and paid productive work on the market and unpaid reproductive, care work in the home, and which social spheres of work should be male and female (Apps and Rees 2009; Gunnarsson 2007; Pfau-Effinger 2004).

\section{Gender issues in personal income taxation (PIT)}

At first glance, gender aspects of taxation are most apparent in personal income taxation. The basic design of income tax schedules and social security contributions affects the disposable after-tax income and incentives to work. The taxation of personal incomes includes personal income taxes and social security contributions. Personal income taxes capture all kinds of personal income regardless of their sources, in particular income from dependent work and self-employment, profits made by non-incorporated firms, capital incomes such as interest, dividend incomes and capital gains. Transfer incomes such pensions and social security payments could also be a part of the income tax base. An indirect part of income taxation consists of social security contributions, which are paid by employees on incomes from dependent work and sometimes also on incomes from selfemployment (Gunnarsson, Schrazenstaller, and Spangenberg 2017, 25). 
PIT and social contributions on labour constitutes as well as other taxes and charges based on labour income, constitute almost half of overall tax revenues of the EU Member States (Gunnarsson, Schrazenstaller, and Spangenberg 2017, 22). In contrast, low income and developing countries raise more of their revenue from indirect consumption taxes (Lahey 2018, 16).

\section{Tax schedules and tax base issues}

The world-wide trend in tax policies, as described under section 2, has caused considerable shifts in the structure of income tax rates. The progressivity has fallen. The development in the the EU Member States can serve as an example on different tax law reforms that have contributed to reduced progressivity in the income tax system. One line of reform is the introduction of flat tax regimes, in particularly the transforming economies of the "new" Member States. Another trend in tax reforms, reducing the progressivity, is the dualization of personal income taxation, which is a deviation from the system of global income taxation, justified by the abilityto-pay principle. Global indicates that one tax schedule is applied on all types of income earned worldwide. Almost all EU Member States have dualized their income tax systems by introducing rather moderate uniform tax rates for all or at least some types of capital income. This dualization of income tax systems weakens the redistributive power of income taxation in general. From a gender perspective, dual income tax systems are not able to correct the unequal distribution of capital incomes between men and women, but rather accentuate it. At the same time, the direct progressive tax schedules applied to only labour incomes in many countries, foresee basic income tax rates at substantial levels, thus impairing work incentives particularly for women (Gunnarsson, Schrazenstaller, and Spangenberg 2017, 21-23). In the Nordic European countries, the global tax scheme has been replaced by the a more extreme scheme of reducing the taxation of capital income, the so-called dual income tax model. The dual income tax system, justified by principles on neutrality and uniformity, applies separate tax schedules to the individual income sources, taxing capital incomes at relatively moderate flat tax rates, while subjecting other 
incomes, in particular labour incomes from dependent work and selfemployment, to partly progressive income tax schedules (Sørensen 2010b).

Sweden can serve as an extreme example on how the Nordic dual income tax model, has created a huge tax wedge between capital and earned income by combining a progressive tax on earned income with a low flatrate tax on capital income (Gunnarsson 2020; Sørensen 2010a). In reality, the dual income tax reform created incentives for unequal tax treatment of equal levels of incomes, which not even lives up to the standards of uniformity. Instead, the tax capital income tax policies have turned into a race-to-the-bottom narrative. The capital income tax base and the tax rate base gradually eroded through several reforms. When, the capital tax rate on dividends from shares in close companies was reduced from 30 per cent to 20 per cent in 2006, the tax wedge increased between capital and labor income to about 35 per cent. The tax cut in combination with a simplification of the income splitting system for close companies, the socalled 3:12 regulations, became a drive for income shifting. Active owners with a majority of votes to tax a part of their profit as dividends under the scheme of as capital income tax instead of wages under the tax scheme of labor income. Empirical evidence shows an obvious change in behavior on both individual and company level after the 2006 reform. One of them is the increase of dividend income by over 80 per cent in close companies. High-income active owners benefited most from the income shifting. (Alstadsæter and Jacob 2012; Hilling, Sandell and Wilhelmsson 2017; Lodin and Englund 2017). Statistics from the long-term survey of the Swedish economy confirms the increase of capital income as a result of incomeshifting from high taxed earned income to low taxed capital income, but also points at an overall increase of capital income in society. An analyse delivered by the survey is that the increase of capital income has the income inequality (SOU 2019:65). A report from the Skatteverket, the Swedish tax authority, shows that the number of male taxpayers declaring earned income has decreased with 13 per cent during the years 2005-2016. The explanation is the same as the survey, the share of low-taxed capital income has increased. Skatteverket make the analyse that this development has been more beneficial for men, due to the socio-economic gender gaps in 
entrepreneurship and corporates and the gender gaps in both earned and capital income (Skatteverket. 2018).

\section{Tax unit issues}

A common feature of many income tax systems in the world is the creation of tax wedges and inactivity traps for secondary earners. These are main disincentives to women's labor market participation. The main reasons are insufficient recognition of child care costs and joint tax provisions in a family or household-based income tax system (Gunnarsson, Schrazenstaller and Spangenberg 2017, 26-32). A large number of economic studies, based on micro-simulation models prove, that work incentives for women are impaired by joint taxation as well as joint transfers (Fink et al. 2019; Rastrigina and Verashchagina 2015). When certain transfer payments or tax reliefs are contingent on the intra-household distribution of paid work or household income, so that tax rates for secondary earners entering into or extending employment are higher than for single individuals, tax and benefit provisions create a secondary earner bias leading to risks of getting caught in inactivity and low wage traps (Bettio and Verashchagina 2013).

Joint taxation of the family, extended households and spouses has very strong cultural roots. Jointness in income taxation has supported the breadwinner family model by joint filing, allowing income splitting of the household income and the transferability of own income allowances, basic deductions, and loss reliefs between the spouses. Joint taxation is connected to an old tax theory debate occupied with the question of what constitutes tax ability (Gunnarsson 2013).

In the EU Member States, the number of countries applying a conventional joint taxation model is decreasing. However, much of the joint elements in the tax-transfer interface remains in most countries. One of the few exceptions is Sweden, that introduced individual income taxation for earned income already in 1971 in a way that has proved to be sustainable in relation to gender equality law (Gunnarsson and Eriksson 2017).

Among the EU Member States the majority of working women in couples usually are secondary earners, earning on average about one-third of a couple's joint income. Joint provisions were initially only applied to married 
couples but has been extended to include other forms of partnershipps. Replacing the income splitting system by individual taxation would markedly increase female employment. The conclusion is that one of the most critical objectives in taxation remains to eliminate tax-related disincentives to female employment and the unequal distribution of paid and unpaid work (Rastrigina and Verashchagina 2015; Gunnarsson, Schrazenstaller and Spangenberg 2017, 28; Fink et al. 2019). This is the reason to why the European Parliament has, made the demand on the EU Member States, to phase in full individual taxation, including the elimination of tax expenditures and benefits based on joint income, serves as a good example of an important step forward (2018/2019 (INI), No. 5, 6, 10).

Globally, the progress towards taxation of women as individuals is slow. In some developing countries, joint filing or income splitting is not even voluntary, even though a move towards the right to file individually is noted for example in countries in the MENA-region and in the in Thailand that can serve as one example from the Asian region (Lahey 2018, 24-25). Even though the right to individual filing is the main rule in developed countries, a contradictory tax policy trend among OECD countries since the 1990s is the use of various types of joint family income tested tax credits and family benefits, which have had the same lock-in effects on co-habitant women's labour supply as joint taxation (Gunnarsson 2013). Australia's Family Tax Benefit system can serve as an example on a joint income-tested benefit for families supporting children, that has shifted the tax burden towards working mothers living in partnership that and has widened the net-of-tax gender gap (Apps 2017).

Obviously, there exists several aspects on tax efficiency and equity on the link between the extensive support over the tax system of the bread-winner family model and the tax disincentives to women's labour market supply impacting the gendered inequality in the distribution of paid and unpaid work. 


\section{Tax expenditures}

Tax expenditures is a concept that refers to fiscal measures that deviates from the ideology of the tax system. It is used to target tax measures that in reality are spending programmes. The gender budgeting movement has used the concept to demonstrate the gender blindness in conventional budget policies (Gunnarsson 2013). The concept to pin-point what could be deviations from a standard tax treatment is mostly normative and differs from country to country, but can also have a provisional base. That is the case regarding the Swedish example above on the treatment of capital income. The Swedish government is due to the Budget Law (2011:203), obliged to account for tax expenditure in the annual budget. However, the benchmark for standard tax treatment is decided in a normative manner formulated as comparative norm based in the principle of uniformity in taxation, which is expressed as each tax base should be taxed uniformly. Exceptions are regarded as tax expenditures (Skr. 2019/20:98). From this benchmark follows that the reduced tax rate on capital income for close companies officially is regarded as a tax expenditure. The non-uniform treatment of capital income also give evidence to the claim that tax expenditures are less beneficiary for women than men. Much more research needs to be done on the gendered impact of tax expenditures (Gunnarsson, Schrazenstaller and Spangenberg 2017, 33-34).

\section{Gender issues in indirect consumption taxation}

VAT has distributional effects. One of them is connected to the price elasticity of demand. A low-price elasticity means that the demand hardly responds to changes in the tax rate. High rates on goods and services with low price elasticity are vertically inequitable in the sense that poor people will pay a larger portion of their incomes on basic commodities. Of course, not all goods and services with low price elasticity are basic commodities. Tobacco and alcohol are examples on the latter. There has been a longstanding debate and increasing concern that the burden of VAT falls disproportionately on women, but there is an overall lack of research based on gender-disaggregated data that can show what impact specific rates and exemptions have in relation to certain consumption patterns. As women are 
generally over-represented among the poorest in a society, and due to the gender pay gap, also are over-represented in the lowest income deciles, they would spend a higher percentage of their income on consumption compared to individuals in higher income groups (Gunnarsson, Schrazenstaller and Spangenberg 2017; Joshi 2016).

This regressive effect has been questioned, particularly from a lifetime perspective. Using lifetime income as a reference for the incidence of VAT, instead of annual income, the regressive effects of VAT have been proven to be significantly lower (see for example Caspersen and Metcalf 1994). The lifetime perspective is not a problem in itself, but when used as a legitimizing argument for tax neutrality principles that promotes the uniformity of VAT tax rates and tax basis, the perspective becomes political. This was the case in the 1991 Swedish tax reform, that also coincides with principles expressed in other major national reforms at the time and later with the fiscal consolidation programs launched as a result of the economic crisis 2007/08 and 2010/11 (Gunnarsson 1995; Gunnarsson 1999; Gunnarsson, Schrazenstaller and Spangenberg 2017). Hereby, the tax neutrality neglects the annual perspective of low-income individuals with no possibility to borrow or without savings to consume. For them an increase of VAT on basic commodities is immediate and absolute for the well-being of that person (Murphy 2010).

Instead of considering the isolated distributional effects in terms of rates and base issues of the VAT more importance ought to be given to the combined effects of the tax mix. A lesson learnt from the 1991 Swedish reform, as well as reforms from other European countries, is that a tax shift from a progressive income tax with a reduction of the marginal income tax rate combined with an increase of a broad-based VAT with uniform tax rates, will give negative redistributive effects for most women (Gunnarsson 2011; Gunnarsson, Schrazenstaller and Spangenberg 2017).

Related to the regressivity of the VAT, is the assumption that women and men have differential consumption patterns and that women are primarily responsible for household purchases of basic goods and services (Joshi 2016). This argument is particularly relevant for developing countries where commodity taxes, and in particular VAT, are the most important revenue base. An estimate from the beginning of the 2010 decennium, showed that 
on average, low-income countries collected over four times as much revenue from VAT as from personal income taxes, and in middle-income countries VAT revenues were rapidly approaching the same level (Cottarelli 2011).

Studies on developing countries also show a complex pattern of zero rating, differentiated rates and exemptions of basic commodities, partly questioning and partly supporting a tax policy strategy of using VAT and other indirect taxes in social and redistributive programmes such as fighting poverty (Barnett and Grown 2004; Bernadette and Were 2011). A study from South Africa implies that the indirect tax structure can be redistributive in a gender-equal manner. This outcome has been achieved as an effect of a zero-rated, well-targeted basket of food items and paraffin, which is consumed at a much larger budget share by poor women-headed households. As households headed by men spend a large budget share on high-taxed consumption such as tobacco, alcohol and fuel, a heavier tax burden falls on men (Casale 2012).

\section{Gender issues in corporate income taxation}

Corporate taxation is often assumed to have no gender impact, as corporations are legal entities without a specific gender and only taxes on individuals are considered to have an impact on gender equality. But corporates are also people (Infanti 2015), and the perspective ignores gender differences in ownership of businesses and shares, different business profiles regarding investors, employees, and consumers, and the distributional consequences of the overall tax structure (Women's Budget Group 2016; Hodgson and Sadiq 2016). Corporate taxation also contains complex issues associated related to transnational corporate income tax practise.

A comprehensive analytical framework to examine gender implications of corporate taxation does not exists; there are only very few analyses of partial aspects to be found in the literature. One factor causing this research gap is the lack of data. A first step to analyse the gender impact of corporate taxation is sufficient gender-disaggregated data with regard to the owners of businesses, shareholders, and employees. Gender impact assessments for 
tax incentives may also require gender-disaggregated data concerning the size, the year of formation, or the legal status of a company (Women's Budget Group.2016, 16).

However, some gender aspects of the distributional impact of changes in corporate taxation have been made. It can be assumed that the direct benefit women derive from an increase in after-tax corporate profits resulting from corporate tax reductions is smaller compared to men, as women are considerably under-represented in the group of business owners or corporate shareholders. The taxing for growth policy has also promoted reductions of personal income tax rates on capital income, accompanied by considerable reductions of corporate income tax rates, significantly lowering the overall tax burden on capital income, from which men presumably benefited disproportionately (Gunnarsson, Schrazenstaller and Spangenberg 2017, 35).

The tax base or tax liability is often reduced by tax expenditures intended to promote particular activities undertaken by businesses, such as investment in research and development (R\&D), or aimed at supporting particular groups of firms, such as small and medium-sized enterprises (SMEs). These kinds of tax incentives take numerous forms, such as higher tax allowances for certain costs incurred by businesses, lower tax rates for business income from certain sources, or for certain types of business. 25 Member States, for instance, are currently using fiscal incentives to encourage investment in research and development. Studies evaluating these kinds of incentives completely neglect gender implications. However, tax incentives granted to firms and business owners, respectively, may exert gender-differentiated effects, if participation rates of women in the particular subgroup of firms differ from those of men. Examples are tax incentives granted to early-stage entrepreneurs, among which women tend to be under-represented. Also, firm size and profitability play a role; tax allowances do not benefit firms which are too small to pay tax (Gunnarsson, Schrazenstaller and Spangenberg 2017, 35-36). Data for the UK, for example, show that, on average, businesses owned by women are smaller compared to those in male ownership. Therefore, tax incentives may widen existing gaps between male and female new venture and business creation (Women`s Budget Group 2011). 


\section{Gender issues regarding tax evasion}

Internationalization of economies, have increased mobility of capital, corporate profits and wealth, incentivizing tax competition between jurisdictions, but also the behavior of taxpayers expressed in a practice to reduce the tax liability. The international tax arena has opened up for a vast field of tax minimization strategies, which have become a major global issue, containing a multitude of complex problems. Aggressive tax planning, harmful tax practices, illicit financial flows, tax fraud, tax abuse, tax evasion and tax avoidance are tax concepts used in this tax planning. Formally, most of these tax schemes are legal, but seen as unethical and foremost, not so obedient to the intention to the law. Some concepts are the result of an active tax competition between countries, but far from all. Much of the tax planning by multinational enterprises consists of profit-shifting to minimize corporate tax payments and exploiting nominal tax rate differentials between jurisdictions, or making use of special tax regimes including "treaty shopping to their advantages (Hearson 2014). These tax behaviors and schemes have undesirable distributional effects also from a gender perspective. The loss of corporate revenue in home countries leads to both a less of revenue that reduces the capacity to invest in genderequality promoting reforms, and a shift to less mobile tax bases that tend to burden women disproportionately (Gunnarsson, Schrazenstaller and Spangenberg 2017, 36; Lahey, 2018, 38).

Tax havens, today more correctly defined as secrecy jurisdictions to emphasize the legal characteristics of tax and financial schemes, are a great threat to revenue raising and redistribution over the fiscal system. An enormous amount of the world's wealth is hidden in tax havens, outside the scope of tax liability in any national state. Not until Gabriel Zucman (2015) presented his research on quantifying the hidden wealth, an insight about the enormous sum of revenue loss was reached. Secrecy, make it impossible to see the whole picture, but more and more figures are presented, such as a figure from Latin-America suggesting that tax evasion and avoidance did mount up to 6,3\% of GDP in the region during 2017 (Fiscal Panorama 2019).

After the financial crisis the insights about the need for taking more measures to limit the damaging effects for domestic revenue mobilization 
in both developed and developing countries have emerged. Not surprisingly, developing countries have been neglected in the multilateral institution driven policy research on tax havens (Cobham 2012). The history of neglect in treating developing countries as equal partners or equally important in the international collaboration necessary to take action against national revenue losses, fuels the already very destructive spiral of legitimacy problem in developing countries (South Centre Tax Initiative 2020).

Post-colonial states in particular have a huge legitimacy deficit, originally related to the use of taxing power as the power to take. An analyze of the fiscal legitimacy situation in African countries, which probably is applicable on many other post-colonial states, are the problems with layers of corruption, cultural, social and economic diversity, poor governance, incoherent and underdeveloped domestic tax laws, international interference trough aid and loan programs, and maybe most important av very low degree of fiscal re-distribution of revenue for the human well-being of citizens (Waris 2019).

In the wake of the pandemic crisis, and the dramatic need for more and new sources of revenue, a much more confrontative, radical approach in the demand for new actions in tax policies can be noticed. The Directorate for taxes and customs in the EU (Taxud) ${ }^{2}$ has delivered very strong opinions on tax evasion and avoidance, and the huge sums lost in tax havens. The untaxed sources of wealth is now in focus and IMF (2020) has proposed the introduction of 'solidarity surcharges' on wealth.

The context of tax evasion has an obvious gender equality dimension, which is expressed by the Bogota-declaration as well as by UN institutions. The CEDAW Committee has made an interesting statement, when expressing concern about Switzerland's financial secrecy policies and rules on corporate reporting and taxation, because these regulations have the potential to diminish the ability of other states to mobilise the maximum available resources, necessary for the fulfilment of women's rights. The committee recommended independent, participatory and periodic impact assessments of the extraterritorial effects on women's rights and

\footnotetext{
${ }^{2}$ https://ec.europa.eu/taxation_customs/fight-against-tax-fraud-tax-evasion/a-huge-problem_en.
} 
substantive equality, to be conducted in an impartial manner with public disclosure of the methodology and findings (CEDAW/C/CHE/CO/4-5 (2016), para $40 \mathrm{c}$ ).

\section{Concluding discussion: Is there a hope for women's tax justice?}

Tax laws obviously have a substantial outcome on gender-related socioeconomic realities. And obviously policymakers and legislators have not taken this problem seriously in a magnitude that even have violated a number of legal obligations and policies on national, regional and international levels. Not even Sweden, one of the top four Nordic countries in the World and associated with individual income taxation, gender equality laws and policies that promotes substantive equality, have managed. As presented in the article, an insight has grown that this neglect will become a huge challenge for the increasing income and wealth inequalities in the world. Inclusive growth, as well as declarations from powerful actors in the wake of the pandemic crisis about the need to consider human rights and the well-being of citizens, seems to be new concepts to consider in new directions for tax policies. A thorough understanding of gender aspects in tax policies, the implementation of legal and political requirements and the realization of gender equality require many reforms and further research to improve the knowledge base. It is not enough to only address the underlying socioeconomic differences as one reason for gender differentiated outcomes of the tax system. A call for changes in the tax system itself is also necessary. There is no room for more of the same in future tax reforms. 


\section{References}

Andersson-Skog, Lena. 2007. In the shadow of the Swedish welfare state: women and the service sector. Business history review, Vol. 81, 451-470. Alsos, Gry, Hytti, Agnete, Ulla and Ljunggren, Elisabet. 2016. Gender and innovation - an introduction Research Handbook on Gender and Innovation (2016), 3-16.

Alstadsæter, Anette and Martin, Jacob. Income Shifting in Sweden: An empirical evaluation of the 3:12 rules. Report to the Expert Group on Public Economics 2012(4). Stockholm, Ministry of Finance, 2012. Apps, Patricia. 2017. Gender equity in the tax-transfer system for fiscal sustainability. In Tax, Social Policy and Gender. Rethinking equality and efficiency, edited by Miranda Stewart. Australian National, University Press.

Apps, Patricia and Ray Rees. 2009. Public Economics and the Household. Cambridge University Press.

Barnett, Kathleen and Caren Grown. 2004. Gender Impacts of Taxation: A Review of the Literature: Commonwealth Secretariat.

Bernadette M and Maureen Were. 2011. Gender and Taxation in Kenya: The Case of Personal Income and Value-added Taxes. In: Brooks, et al., 255274.

Bettio, Francesca and Alina Verashchagina 2013. Current Tax-Benefit Systems in Europe: Are They Fair to Working Women? In: Bettio, Francesca, Janneke Plantenga \& $\mathrm{m}$. Smith (eds). Gender and the European Labour Market. Abingdon/Oxon, 168-198.

Bogota-declaration.

https://www.globaltaxjustice.org/sites/default/files/EN_BogotaDeclaration-Tax-Justice-for-Womens-Rights_0.pdf.

Brooks, Kim, Gunnarsson, Åsa, Philipps, Lisa and Wersig, Maria. 2011. Challenging Gender Inequality in Tax Policy Making: Comparative Perspectives. Oxford: Hart Publishing.

Brys, Bert, Perret, Sarah, Thomas, Allistar and O’Reilly. 2016. "Tax Design for Inclusive Economic Growth”. OECD Taxation Working Papers No 26 <https://doi.org/10.1787/5jlv74ggk0g7-en: accessed 25 July 2020. 
Casale, Daniela Maria. 2012. Indirect Taxation and Gender Equity: Evidence from South Africa. Feminist Economics, 18:3, 25-54.

Caspersen, Erik and Metcalf, Gilbert E. 1994. Is a Value Added Tax Regressive? Annual Versus Lifetime Incidence Measures, National Tax Journal, 47 (4), 731-46.

Cingano, Federico. 2014. "Trends in Income Inequality and its Impact on Economic Growth.” OECD Social, Employment and Migration Working Papers No. 163.

Cobham, Alex, 2012, Tax Havens and Illicit Flows. In Reuter, Peter, Draining Development? Controlling Flows of Illicit Funds from Developing Countries. The World Bank.

Cottarelli, Carlo. 2011. Revenue Mobilization in Developing Countries. IMF.

Cuberes, David and Mark Teignier. 2016. Aggregate Effects of Gender Gaps in the Labor Market: A Quantitative Estimate. Journal of Human Capital, 10(1), 1-32.https://doi.org/10.1086/683847.

Demirguc-Kunt, Asli, Klapper, Leora, Singer, Dorothe and Van Oudheusden, Peter. 2015. The Global Findex Database 2014: Measuring Financial Inclusion around the World. Policy Research Working Paper 7255. Washington, D.C., World Bank. Available at: http://documents.worldbank.org/curated/en/187761468179367706/pdf/ WPS7255.pdf

Diamond, Peter and Emmanuel Saez. 2011. "The Case for a Progressive Tax. From Basic Research to Policy Recommendations." The Journal of Economic Perspectives 25 (4): 165-190.

Elson, Diane and Fontana, Marzia. 2019. "Conceptualizing GenderEquitable Inclusive Growth.” In Gender Equality and Inclusive Growth: Economic Policies to Achieve Sustainable Development, edited by Elson, Diane and Marzia, Fontana, Marzia. UN.

Elson, Diane, 2006, Budgeting for Women's Rights. Monitoring Government Budgets for Compliance with CEDAW. New York: UNIFEM.

European Parliament, Resolution on gender equality and taxation policies in the EU, 2018/2019 (INI), No. 34.

Ferrante, Gaëlle and Alexandre Kolev. 2016. "Does gender discrimination in social institutions matter for long-term growth? Cross-country 
evidence.” OECD Development Centre Working Papers, No. 330, OECD Publishing, Paris, https://doi.org/10.1787/5jm2hz8dgls6-en

Fiscal Panorama of Latin America and the Caribbean. 2019.

Fink, J, Janová, D. Nerudova, J. Pavel, Margit, Schratzenstaller, F.

Sinderman, M. Speilauer: Policy Recommendations on the Gender

Effects of Changes in tax Bases, Rates and Units. Results of

Microsimulation Analyses for Six Selected EU Member States, FairTax

Working Paper Series 2019, No. 24.

Fredman, Sandra. 2013. Engendering socio-economic rights. In A. Hellum \&

H. Aasen (Eds.), Women's Human Rights: CEDAW in International,

Regional and National Law (Studies on Human Rights Conventions, pp.

217-241). Cambridge: Cambridge University Press.

doi:10.1017/CBO9781139540841.011.

Förster, Michael, Ana, Llena-Nozal and Vahé, Nafilyan. 2015. "Trends in Top

Incomes and their Taxation in OECD Countries." OECD Social,

Employment and Migration Working Papers No 159.

Grown, Caren \& Imraan Valodia (eds.). 2010. Taxation and Gender Equity: A

comparative analysis of direct and indirect taxes in developing and

developed countries, London/New York: Routledge.

Gaspar, Vitor. Jan 2019. Fiscal Policy and Development: Human, Social, and

Physical Investment for the SDGs. IMF Staff Discussion Noe (SDN/19/03).

Gunnarsson, Åsa. 2020. “Taxing for Social Justice or for Growth?” In Tax Justice and Tax Law: Understanding Unfairness in Tax Systems, edited by Dominic de Cogan and Peter Harris. Hart Publishing.

Gunnarsson, Åsa. 2018. “The Making of a Critical Tax Policy Framework.” In

Festskrift till Håkan Hydén, edited by Reza Banakar, Karl Dahlstrand and Lotti Ryberg Welander Lund , Juristförlaget i Lund.

Gunnarsson, Åsa and Martin Eriksson. 2017. Eliminating the secondary earner bias. Policy lessons from the introduction of partial individua income taxation in. Sweden 1971. Nordic Tax Journal, 89-99.

Gunnarsson, Åsa, Margit, Schratzenstaller and Ulrike, Spangenberg. 2017. Gender equality and taxation in the European Union. Research paper for European Parliament's Committee on Women's Rights and Gender Equality and commissioned, overseen and published by the Policy 
Department for Citizen's Rights and Constitutional Affairs.

http://www.europarl.europa.eu/supporting-analyses.

Gunnarsson, Åsa. 2013. "Gendered Power Over Taxes and Budgets.” In The Ashgate Research Companion to Feminist Legal Theory., edited by Davies, Margaret and Munro, Vanessa, E. Ashgate Publishing.

Gunnarsson, Åsa. 2011. "Challenging the Benchmark in Tax Law Theories and Policies from a Gender Perspective - The Swedish Case.” In Challenging Gender Inequality in Tax Policy Making: Comparative Perspectives. Edited by Brooks, Kim, Åsa Gunnarsson, Lisa Philipps, and Maria Wersig. Oxford: Hart Publishing, pp. 75-92.

Gunnarsson, Åsa. 2007. Gender Equality and the Diversity of Rights and Obligations. In Exploiting the Limits of Law. Swedish Feminism and the Challenge to Pessimism., Edited by Åsa Gunnarsson, Eva-Maria Svensson and Margaret Davies. Aldershot: Ashgate, 191-211.

Gunnarsson, Åsa. 1999. Equity Trends in Taxation. In Liber Amicorum to Prof Em Leif Mutén. Kluwer

Gunnarsson, Åsa. 1995. Skatterättvisa (Tax Equity). Iustus förlag.

Hearson, Martin. 2014. Tax-motivated illicit financial flows: A guide for development practitioners. U4, Anti-corruption Resource Centre.

Hilling, Axel, N Sandell and A Wilhelmsson (2017), 'The Planning in Partnerowned Close Corporations' (2017) 1(1) Nordic Tax Journal 108.

Hodgson, Helen and Kerrie, Sadiq. 2016. "Gender Equality and a Rights Based Approach to Tax Reform." 28th Australasian Tax Teachers Association Conference. Tax and Time Travel: Looking Backwards and Looking Forwards. UNSW Business School, Sydney.

IMF. 2020. Special Series on Fiscal Policies to Respond to Covid-19.

IMF (International Monetary Fund). 2018. Pursuing Women's Economic Empowermenthttps://www.imf.org/en/Publications/Policy-

Papers/Issues/2018/05/31/pp053118pursuing-womens-economic-empowerment.

Infanti, Anthony C., 2015. Of Families and Corporations: Erasing the Public-

Private Divide in Tax Reform Debates. In Controversies in Tax Law: A

Matter of Perspective. Ashgate, 2015.

Joshi, Anuradha 2016. Gender and Taxation. ICTD Annual Meeting, 10-12

February 2016. Addis Ababa: ICTD. 
Kornhauser, Marjorie. 2011. Gender and Capital Gains Taxation. In Challenging Gender Inequality in Tax Policy Making: Comparative Perspectives., edited by Brooks, Kim, Gunnarsson, Åsa, Philipps, Lisa and Maria Wersig. Oxford: Hart Publishing, 278-280.

Lahey, Kathleen, A. 2018. Gender, Taxation and Equality in Developing Countries. Issues and Policy Recommendations. UN Women.

Lodin, Sven-Olof and P Englund, Yes box! En ESO-rapport om en ny modell för kapital- och bostadsbeskattning. Rapport till Expertgruppen för studier i offentlig ekonomi 2017:4, Stockholm, Regeringskansliet, Finansdepartementet, 2017.

Messere, Ken (ed). 1998. The Tax System in Industrialized Countries. Oxford University Press.

Mirrlees, James A. 1971. "An Exploration in the Theory of Optimum Income Taxation.” Review of Economic Statistics 38 (2): 175-208.

Mumford, Ann and Gunnarsson, Åsa. 2019. "Sustainability in EU Tax Law." Intereconomics. Review of European Economic Policy, 54(2), 134-137.

Murphy, Richard. July 12 2010. VAT regressive, and if so, why does the IFS deny it? http://www.taxresearch.org.uk/Blog/2010/07/12/is-vatregressive-and-if-so-why-does-the-ifs-deny-it/OECD 2016. Consumption Tax Trends 2016, Paris: OECD Publishing.

OECD (Organisation for Economic Co-operation and Development). 2015. Final NAEC Synthesis, New Approaches to Economic Challenges. http://www.oecd.org/naec/Final-NAEC-Synthesis-Report-CMIN20152.pdf: accessed 25 July 2020.

Ostry, Jonathan, D., Andrew, Berg and Charalambos G., Tsangarides. 2014. Redistribution, Inequality and Growth. International Monetary Fund.

Pfau-Effinger, Birgit. 2004. Socio-historical paths of the male breadwinner model - an explanation of cross-national differences. British Journal of Sociology, 55(3), 377-399.

Piketty, Thomas. 2014. Capital in the Twenty-First Century. Belknap Press of Harvard University Press.

PwC, Women in Work Index 2020. Available at:

https://www.pwc.co.uk/services/economics-policy/insights/women-inwork-index.html

Ragnhild Vada. 2007. Satsning på kvinner som naeringsutövere. Bergen. 
Rastrigina, Olga and Alina Verashchagina. 2015. Secondary earners and fiscal policies in Europe [Online]. Brussels, European Commission.

Saad-Filho, Alfredo. 2010. "Growth, Poverty and Inequality: From Washington Consensus to Inclusive Growth.” DESA Working Paper No. 100.

Saez Emmanuel and Gabriel Zucman. 2019. The Triumph of Injustice: How the Rich Dodge Taxes and How to Make Them Pay. W.W. Norton \& Company 2019.

Sandford, Cedric. 1993. Successful Tax Reform. Lessons from an Analysis of Tax Reform in Six Countries. Bath: Fiscal Publications.

Schmelzer, Mattias. 2016. The Hegemony of Growth. The OECD and the Making of the OECD Growth Paradigm. Cambridge: Cambridge University Press.

Seguino, Stephanie. 2019. "Tools of Macroeconomic Policy: Fiscal, Monetary and Macroprudential Approaches. In Gender Equality and Inclusive Growth: Economic Policies to Achieve Sustainable Development, edited by Elson, Diane and Fontana, Marzia. UN.

Skatteverket. 2018. Skattesystemets utveckling 2006-2015. Fördjupad analys av rut- och rotavdrag, investeringssparkonto och delägare i fåmansbolag ur ett jämställdhetsperspektiv.

Skr. 2019/20:98, Redovisning av skatteutgifter 2020.

South Centre Tax Initiative and the Global Alliance for Tax Justice. 23 July 2020. Webinar on Tax Policy Options for Funding the Post-COVID Recovery in the Global South.

SOU 2019:65, Huvudbetänkande av Långtidsutredningen. Stockholm, Norstedts Juridik, 2019.

Stewart, Miranda. 2017. Gender inequality in Australia's tax-transfer system. In Tax, Social Policy and Gender. Rethinking equality and efficiency, edited by Miranda Stewart. Australian National, University Press.

Stotsky, Janet G. 1996. Gender Bias in Tax System. IMF Working Paper 99/96, Washington: International Monetary Fund.

Sørensen Birch, Peter. 2010a. Swedish Tax Policy. Recent Trends and Future Challenges. Stockholm: Swedish Ministry of Finance. 
Sørensen, Peter, Birch. 2010b. Dual income taxes: a Nordic tax system. In Tax Reform in Open Economies, edited by Claus, Iris, Norman Gemmell, Michelle Harding and David White. Cheltenham: Edward Elgar.

UN (United Nations). 2020. "Shared Responsibility, Global Solidarity:

Responding to The Socio-Economic Impacts of Covid-19. https://www.un.org/Sites/Un2.Un.Org/Files/Sg_Report_Socio-

Economic Impact Of Covid19.P.

UN (United Nations). 2020. “The Impact of COVID -19 on Women.” Policy Brief.

UN Secretary General's High-Level Panel on Women's Economic

Empowerment. 2016. Leave No One Behind: A Call to Action for Gender Equality and Women's Economic Empowerment.

Available at: https://www.empowerwomen.org/Lmedia/files/un\%20women/empowerwomen/resources/hlp\%20briefs/u nhlp\%20full\%20report.pdf?la=en

UN, Resolution adopted by the General Assembly on 25 September 2015, Transforming our world: the 2030 Agenda for Sustainable Development. UN, Resolution adopted by the General Assembly on 27 July 2015, Addis Ababa Action Agenda on the Third International Conference on Financing for Development, 7-9.

UN Women (United Nations Entity for Gender Equality and the Empowerment of Women). July 2018. Facts and Figures: Economic Empowerment.

UN Women (United Nations Entity for Gender Equality and the Empowerment of Women), 2015, Progress of the World's Women 20152016. Transforming Economies, Realizing Rights. New York, 35. Young, F. L., Claire. 2000. Women, Tax and Social Programs: The Gendered Impact of Funding Social Programs Through the Tax System. Ottawa: Status of Women Canada.

Waris, Attiya, 2019. Financing Africa, Bamenda: Langaa.

Women's Budget Group. 2016. The impact on women of the 2016 Budget: Women paying for the Chancellor's tax cuts. Women`s Budget Group 2011. The Impact on Women of the Budget 2011. World Commission on Environment and Development. 1987. Report on Our common future. 
Zucman, Gabriel. 2015. The Hidden Wealth of Nations. The University of Chicago Press. 